\title{
TREX1 wt Allele
}

National Cancer Institute

\section{Source}

National Cancer Institute. TREX1 wt Allele. NCI Thesaurus. Code C51009.

Human TREX1 wild-type allele is located in the vicinity of 3p21.31 and is approximately 3 $\mathrm{kb}$ in length. This allele, which encodes three prime repair exonuclease 1 protein, plays a role in DNA repair. Mutation of the gene is associated with Aicardi-Goutieres syndrome 1, Chilblain lupus, vasculopathy, retinal, with cerebral leukodystrophy, and increased susceptibility to systemic lupus erythematosus. 